\title{
Potassium Hydroxyde Pre-Treatment Enhances Methane Yield from Giant Reed (Arundo donax L.)
}

\author{
Ciro Vasmara ${ }^{1} \mathbb{D}$, Stefano Cianchetta ${ }^{2}$, Rosa Marchetti ${ }^{1}$, Enrico Ceotto ${ }^{2} \mathbb{D}$ and Stefania Galletti ${ }^{2, *} \mathbb{D}$ \\ 1 CREA-Council for Agricultural Research and Economics, Research Centre for Animal Production and \\ Aquaculture, Via Beccastecca 345, 41018 San Cesario Sul Panaro, Italy; ciro.vasmara@crea.gov.it (C.V.); \\ rosa.marchetti@crea.gov.it (R.M.) \\ 2 CREA-Council for Agricultural Research and Economics, Research Centre for Agriculture and Environment, \\ Via di Corticella 133, 40128 Bologna, Italy; stefano.cianchetta@crea.gov.it (S.C.); \\ enrico.ceotto@crea.gov.it (E.C.) \\ * Correspondence: stefania.galletti@crea.gov.it; Tel.: +39-051-631-6836
}

Citation: Vasmara, C.; Cianchetta, S.; Marchetti, R.; Ceotto, E.; Galletti, S. Potassium Hydroxyde Pre-Treatment Enhances Methane Yield from Giant Reed (Arundo donax L.). Energies 2021, 14, 630. https://doi.org/10.3390/ en14030630

Academic Editor: Marcin Dębowski Received: 3 December 2020

Accepted: 22 January 2021

Published: 26 January 2021

Publisher's Note: MDPI stays neutral with regard to jurisdictional claims in published maps and institutional affiliations.

Copyright: (C) 2021 by the authors Licensee MDPI, Basel, Switzerland. This article is an open access article distributed under the terms and conditions of the Creative Commons Attribution (CC BY) license (https:// creativecommons.org/licenses/by/ $4.0 /)$.

\begin{abstract}
The biogas production through the anaerobic digestion (AD) of giant reed (Arundo donax L.) biomass has received increasing attention. However, due to the presence of lignin, a low $\mathrm{CH}_{4}$ yield can be obtained. Aiming to improve the $\mathrm{CH}_{4}$ yield from giant reed biomass, the effectiveness of a thermo-chemical pre-treatment based on $\mathrm{KOH}$ was evaluated in this paper. The usefulness of a washing step before the AD was also assessed. The pre-treatment led to a specific $\mathrm{CH}_{4}$ yield up to $232 \mathrm{~mL} \mathrm{CH}_{4} \mathrm{~g}^{-1}$ VS which was $21 \%$ higher than that from untreated biomass; the maximum daily rate of production was improved by $42 \%$, AD duration was reduced by $10 \%$, and $\mathrm{CH}_{4}$ concentration in the biogas was increased by $23 \%$. On the contrary, the washing step did not improve the AD process. Besides, washing away the liquid fraction led to biomass losses, reducing the overall $\mathrm{CH}_{4}$ production. The use of a $\mathrm{KOH}$-based pre-treatment appears as a good option for enhancing the AD of giant reed, also presenting potential environmental and agronomical benefits, like the avoidance of salty wastewater production and the likely improvement of the digestate quality, due to its enriched K content.
\end{abstract}

Keywords: alkaline pre-treatment; anaerobic digestion; Arundo donax L.; biogas; giant reed; lignocellulosic biomass; methane

\section{Introduction}

The biogas produced through anaerobic digestion (AD) is one of the biofuels on which most attention is focused. Anaerobic digestion is considered an environmentally friendly fuel generation technology as it requires a lower energy input than that required for the production of other biofuels $[1,2]$. Besides, the AD process can rely on the utilization of residual biomass, by-products, or waste. Therefore, in addition to the production of biofuels, AD can contribute to the disposal of these biomasses, and the reduction of the emission of greenhouse gases and other pollutants, generating wastewater that can be used as a high-quality fertilizer $[3,4]$.

The biogas production from lignocellulosic biomasses has received increasing interest due to possible economic and environmental advantages deriving from their use [2]. Lignocellulosic biomasses have a worldwide availability in the order of $1000 \mathrm{Gt}$ per year [2]. Among them, perennial crops can present very high biomass yield and low agronomic input requirements, in terms of fertilizers, tillage, pesticides, and irrigation water [5].

Lignocellulosic biomasses are composed of cellulose, hemicellulose, and lignin; notably, cellulose and hemicellulose are structural carbohydrates that can be converted to $\mathrm{CH}_{4}$ during the AD process [6]. Lignin, on the other hand, is an aromatic polymer with low biodegradability, well suited to resist microbial attacks and oxidative stress [7]. The three constituents of the lignocellulosic biomass are inherently connected, resulting in a substrate 
relatively recalcitrant to the $\mathrm{AD}$ process. Thus, the pre-treatment of these biomasses is a viable strategy for enhancing the bioconversion process [6].

The AD performances are strictly related to the effectiveness of the pre-treatments, which can be divided into mechanical, thermal, chemical, and biological, and can also be combined [6-8]. Among chemical pre-treatments, alkaline pre-treatments increase the porosity of lignocellulosic materials, dissolving lignin through the solvation and saponification of the ester bonds between lignin and holocellulose, releasing the structural carbohydrates and making them available for $\mathrm{AD}$ [9]. The thermal pre-treatment of lignocellulosic biomass has been extensively studied [1]. The combination of thermal and alkali pretreatments can increase biomass degradation, however, thermo-alkaline pre-treatments can generate microbial inhibitors, such as polyphenols resulting from the degradation of lignin $[7,10,11]$, dissolved in a salty alkaline solution. Commonly, the removal of the inhibitors before the $\mathrm{AD}$ process or the enzymatic hydrolysis is made by washing the biomass with concurrent organic matter loss and generation of liquid wastes that are generally discarded $[12,13]$. Although the washing step is considered necessary, to date, specific studies are lacking.

In recent years, the perennial grass giant reed (Arundo donax L.) has received great attention due to its high biomass yield [14,15]. Despite the high degree of recalcitrance to enzymatic digestibility [16], little is known about the most suitable pre-treatments for this species. One of the best options to improve $\mathrm{CH}_{4}$ yield from giant reed is the pre-treatment with $\mathrm{NaOH}$, followed by a washing step [17]. However, the wastewater generated is poorly suited to agronomic use due to the presence of $\mathrm{Na}$, which may lead to soil degradation in the long term [18]. A KOH-based pre-treatment could be more appropriate mainly because the resulting wastewater could be utilized as fertilizer in agriculture [19]. To date, the production of $\mathrm{CH}_{4}$ from giant reed has been studied by applying hydrothermal pre-treatments at high temperatures (up to $230{ }^{\circ} \mathrm{C}$ ), or at low temperatures $\left(24-25^{\circ} \mathrm{C}\right.$ ) with an alkali $[12,17,20]$; information on the effectiveness of combined thermo-alkaline pre-treatments is still lacking. Notably, the use of $\mathrm{KOH}$ to pre-treat giant reed to enhance $\mathrm{CH}_{4}$ yield has never been reported. This study aimed at evaluating the effect of the thermochemical pre-treatment of giant reed biomass with $\mathrm{KOH}$ on $\mathrm{CH}_{4}$ yield. To our knowledge, this is the first study exploring this combination on giant reed. The actual need for a washing step before $\mathrm{AD}$ was also evaluated by comparing the $\mathrm{CH}_{4}$ production in reactors fed with washed or unwashed pre-treated biomass of giant reed.

\section{Materials and Methods}

\subsection{Feedstock}

Representative samples of giant reed aboveground biomass were collected in January 2017 from a two-year crop stand at the experimental station of CREA located at Anzola dell'Emilia (Bologna, northern Italy, Lat. $44^{\circ} 32^{\prime} \mathrm{N}$, Long. $11^{\circ} 11^{\prime} \mathrm{E}, 38 \mathrm{~m}$ a.s.l), then they were oven-dried at $65{ }^{\circ} \mathrm{C}$ until constant weight (dry matter, DM), milled at $1.5 \mathrm{~mm}$, and sieved to pass a $1 \mathrm{~mm}$ screen. Samples were collected and stored at room temperature in plastic bags.

The fiber composition and other quality traits of the dry milled giant reed biomass are reported in Table 1 (see Section 2.7 for the analytical methods).

\subsection{Experimental Design}

The following treatments were compared: $\mathrm{K}: 0.135 \mathrm{~g} \mathrm{KOH} \mathrm{g}^{-1}$ of volatile solids (VS) at $121^{\circ} \mathrm{C}$ for $20 \mathrm{~min} ; \mathrm{T}: 121^{\circ} \mathrm{C}$ for $20 \mathrm{~min}$; Kw: $\mathrm{K}$ followed by a washing step, $T w: T$ followed by a washing step; GR: untreated control. Therefore, the milled and sieved giant reed biomass was hydro-thermally pre-treated with or without $\mathrm{KOH}$. Reactors without $\mathrm{KOH}$ were included to estimate the temperature and pressure contribution to the pre-treatment effectiveness. Then, the pre-treated materials were either washed or left unwashed before inoculation and biogas production monitoring. 
Table 1. Fiber composition and other quality traits of the dry milled giant reed biomass.

\begin{tabular}{ccc}
\hline Trait & Mean (SD) \\
\hline Total solids (TS), \%FW 1 & $(0.02)$ \\
Volatile solids (VS), \%FW & 94.81 & $(1.80)$ \\
Ash, \%FW & 89.62 & $(0.01)$ \\
pH in water & 5.19 & $(0.30)$ \\
Total N, \%DM 2 & 5.40 & $(0.05)$ \\
Total C, \%DM & 0.39 & $(0.60)$ \\
Total P, \%DM & 46.70 & $(0.00)$ \\
C/N, mol/mol & 0.05 & $(21)$ \\
Cellulose, \%DM & 142 & $(1.5)$ \\
Hemicellulose, \%DM & 43.1 & $(0.8)$ \\
Lignin, \%DM & 23.6 & $(0.5)$ \\
\hline
\end{tabular}

${ }^{1}$ Percentage of fresh weight; ${ }^{2}$ Percentage of dry matter.

The experiments were performed according to a completely randomized block design with 5 treatments and 3 replicates, for a total of 15 experimental units.

The pre-treatments and the washing step were carried out as described below.

\subsection{Pre-Treatments without Washing Step}

The $\mathrm{K}$ and $\mathrm{T}$ pre-treatments were performed in triplicates at $121{ }^{\circ} \mathrm{C}$ for $20 \mathrm{~min}$ in $100-\mathrm{mL}$ glass reactors closed with rubber stoppers and aluminum seals. The reactors contained an amount of giant reed powder corresponding to $1.00 \mathrm{~g}$ VS and $9.00 \mathrm{~g}$ of distilled water ( $\mathrm{T}$ reactors) or $9.00 \mathrm{~g}$ of a titrated $\mathrm{KOH}$ solution suitable to obtain a final concentration of $0.135 \mathrm{~g}$ of $\mathrm{KOH}$ per $\mathrm{g} \mathrm{VS}$ of giant reed (K reactors). The reactors were left closed to cool at room temperature until the inoculation for the AD experiments.

\subsection{Pre-Treatments with Washing Step}

The Kw and Tw pre-treatments were performed in triplicates at $121^{\circ} \mathrm{C}$ for $20 \mathrm{~min}$ in $250 \mathrm{~mL}$ Erlenmeyer flasks. The flasks contained giant reed powder corresponding to $10.0 \mathrm{~g}$ VS and $90.0 \mathrm{~g}$ of distilled water or $\mathrm{KOH}$ solution at the same final concentration reported above. The flasks were maintained closed and left to cool at room temperature before the washing step. The pre-treated insoluble fractions were separated from the liquid fractions by vacuum filtration (pore size $0.45 \mu \mathrm{m}$ ) and washed with distilled water until neutrality to eliminate possible inhibitors (hereinafter "the washing step"). The solid fractions were oven-dried at $60^{\circ} \mathrm{C}$ until constant weight and aliquots were used for the AD experiments, after VS determination, whereas the remaining parts were frozen for further analysis.

\subsection{Anaerobic Digestion}

After the pre-treatments, all the reactors ( $\mathrm{K}, \mathrm{T}, \mathrm{Kw}, \mathrm{Tw}$, in triplicates), as well as 3 reactors fed with untreated giant reed (GR), were prepared as follows: each reactor contained $1 \mathrm{~g}$ VS and $41 \mathrm{~mL}$ of sterile potassium phosphate-buffered medium (based on ATCC medium \#2825) without carbon sources as hydration medium (HM) in a final volume of $50 \mathrm{~mL}$. When necessary, an appropriate amount of distilled water was also added to reach $50 \mathrm{~mL}$ of final volume ( $\mathrm{Kw}, \mathrm{Tw}$, and GR reactors).

Before inoculation, the $\mathrm{pH}$ was checked in all the reactors and it resulted equal to $7.3 \pm 0.1$, on average, due to the buffering effect of the addition of the relatively large volume of HM. Thus, it was not necessary to adjust it. The reactor headspace was gassed using $100 \% \mathrm{~N}_{2}$ throughout all the preparation steps before inoculation. Each reactor was inoculated with $5 \mathrm{~mL}$ of inoculum. The inoculum used $\left(52.9 \pm 0.3 \mathrm{~g} \mathrm{VS} \mathrm{L}^{-1}\right)$ was prepared according to Vasmara et al. [21], using pig slurry as raw material.

Anaerobic digestion was carried out in $118.5 \mathrm{~mL}$ reactors as previously described [22]. The reactors were plugged with butyl rubber stoppers and aluminum seals and they were incubated at $35^{\circ} \mathrm{C}$ for 91 days. Biogas production and composition were monitored during the whole incubation period. The cumulative $\mathrm{CH}_{4}$ volume was calculated as the sum of 
the methane collected in the syringe and that accumulated in the headspace of the reactors and expressed in standard conditions (STP) of temperature (273 K) and pressure (101 kPa). The incubation period was considered completed when the biogas production stopped in all the reactors. Reactors containing only inoculum and HM were also included as blanks. In the blank reactors, methane production was not observed.

\subsection{Parameters of the Cumulative Methane Production Curves (Gompertz Parameters)}

A modified three-parameter Gompertz equation (Equation (1)) was adopted in this study to describe the time course of cumulated $\mathrm{CH}_{4}$ production [21]:

$$
M(t)=M_{\max } \exp \left\{-\exp \left[\left(\frac{e R_{\max }}{M_{\max }}\right)(\lambda-t)+1\right]\right\}
$$

where $M(t)\left(m L \mathrm{CH}_{4(S T P)}\right)$ is the total quantity of $\mathrm{CH}_{4}$ produced at the culture time $t(d)$ in standard conditions (STP) of pressure $(101 \mathrm{kPa})$ and temperature $(273 \mathrm{~K}) ; e$ is the Euler's number; $M \max \left(m L \mathrm{CH}_{4}\right)$ is the maximum cumulative $\mathrm{CH}_{4}$ production; $\mathrm{Rmax}\left(m L \mathrm{CH}_{4} d^{-1}\right)$ is the maximum daily rate of $\mathrm{CH}_{4}$ accumulation; and $\lambda$ is the lag time duration (d), that is the time of microbial adaptation before the exponential phase of $\mathrm{CH}_{4}$ production begins. This function is often used to interpolate microbial growth curves [23].

Since in each reactor $1 \mathrm{~g}$ VS was present, Mmax corresponds to the specific methane yield ( $S M Y$ ) which represents the $\mathrm{CH}_{4}$ yield obtainable from a specific substrate, expressed as $\mathrm{mL} \mathrm{CH}_{4} \mathrm{~g}^{-1} \mathrm{VS}$. The actual methane production $(A M P)$, which accounts for biomass losses, was calculated as the value of $S M Y$ multiplied by the percentage of retained VS. This percentage refers to VS still present in the sample after the washing step. The AD duration was calculated as the time required to reach Mmax (Time ${ }_{\text {Mmax }}$ ), by adding the $M \max / R \max$ value to the length of the lag phase $(\lambda)$.

\subsection{Analytical Methods}

Biogas composition in the reactor headspace was measured by means of a MicroGC Agilent 3000 gas chromatograph, equipped with 2 columns: Molsieve and Plot U; carrier gas: argon; detector: TCD.

Total solids (TS), VS, ash, total $\mathrm{P}$ concentration, and $\mathrm{pH}$ were determined according to standard methods [24] on the oven-dried, milled, and sieved biomass of giant reed and on washed pre-treated materials. TS were determined gravimetrically by thermal treatment at $105^{\circ} \mathrm{C}$ at a constant weight. VS were determined as the difference between TS and ash. Ash was determined by incineration in a muffle furnace at $550{ }^{\circ} \mathrm{C}$ for $10 \mathrm{~h}$.

Total $\mathrm{C}$ and total $\mathrm{N}$ were determined in duplicate by means of CHN Truspec (Leco). The $\mathrm{pH}$ was determined after suspension, 2-h stirring and sedimentation of $1.1 \mathrm{~g}$ dry matter in $50 \mathrm{~mL}$ distilled water, by means of a Crimson Titromatic $1 \mathrm{~S} \mathrm{pH}$ meter.

Fiber fractions were assessed on samples dried at $65{ }^{\circ} \mathrm{C}$ until constant weight, determining neutral detergent fiber (NDF), acid detergent fiber (ADF), and lignin (ADL), according to Van Soest et al. [25]. The hemicellulose content was estimated as the difference between NDF and ADF, while cellulose was estimated as the difference between ADF and ADL.

To calculate the retained fraction of the various organic fractions of interest (VS, hemicellulose, cellulose, and lignin) they were normalized based on TS losses after the washing step as follows (Equation (2)):

$$
\text { Retained fraction }=\frac{O F \times T S_{r}}{O F_{i n i}}
$$

where $O F$ is the organic fraction of interest in \% dry matter $(\mathrm{DM}), T S_{r}$ is the retained percentage of TS after the washing step, $O F_{i n i}$ is the initial organic fraction of interest in $\% \mathrm{DM}$. 


\subsection{Enzymatic Saccharification of the Pre-Treated Samples and Reducing Sugar Determination}

The samples of the pre-treated materials, obtained from $5 \mathrm{~g}$ of milled giant reed, were saccharified in $250 \mathrm{~mL}$ Erlenmeyer flasks (final volume of $50 \mathrm{~mL}$, in triplicates). Each flask contained the washed or not washed lignocellulosic materials, citrate buffer $50 \mathrm{mM}, \mathrm{pH} 4.8$, sodium azide $\left(0.2 \mathrm{mg} \mathrm{mL}^{-1}\right)$, and a mix of commercial cellulase enzymes (300 $\mu \mathrm{L} /$ flask) (SAE0020, Sigma Aldrich). The flasks were continuously mixed in an orbital shaker $\left(180 \mathrm{rpm}, 50^{\circ} \mathrm{C}, 72 \mathrm{~h}\right)$. Samples of $20 \mu \mathrm{L}$ were withdrawn at $0 \mathrm{~h}$ and $72 \mathrm{~h}$, kept in ice during manipulation, then stored at $-20^{\circ} \mathrm{C}$ before analysis for reducing sugars. Reducing sugars were quantified by the 3,5-dinitrosalicylic acid (DNS) method [26] adapted for 96-well microplates, in duplicates [27]. Dilutions of glucose and the enzyme mix were included, as standards.

\subsection{Statistical Analysis}

All the statistical analyses were performed using the SAS package procedures [28]. The fitting of the Gompertz model to measurements was done using the PROC NLIN. The Gauss-Newton method was used to estimate parameter values. The PROC MIXED procedure [29] was used to test the significance of the treatment effects on AD parameters. The SAS LSMEANS statement was used for multiple comparisons of the means. Factors and factor interaction effects were considered significant at $p<0.05$. To compare the treatment mean values, the Tukey Honestly Significant Difference (HSD) at $p=0.05$ was used.

\section{Results and Discussion}

The pre-treatment aims to deconstruct lignocellulosic biomass to make the holocellulose available for attack by microbial enzymes. Therefore, an effective pre-treatment enhances the biomass hydrolysis, which can be more or less accentuated depending on the pre-treatment severity, as well as on the initial biomass composition. The $\mathrm{KOH}$ rate, and pre-treatment temperature and duration used in this work are based on previous observations when pre-treating giant reed with $\mathrm{NaOH}$ at $120^{\circ} \mathrm{C}$ [30]. These authors reported that both delignification and sugar yield (after enzymatic hydrolysis) steadily increased with raising $\mathrm{NaOH}$ concentration up to $1 \% w / w$, while a plateau was finally reached at slightly higher concentrations $(1.2-1.5 \% w / w)$. Thus, the pre-treatment conditions applied in this study were chosen to guarantee an effective fiber deconstruction, being $\mathrm{KOH}$ molarity comparable to that of $\mathrm{NaOH} 1 \% w / w$, and time and temperature being the same as those used in the previous study.

\subsection{Pre-Treatment Efficiency and Effects on the Biomass}

To have a confirmation of the effectiveness of the pre-treatments applied, an enzymatic saccharification test had been performed on the differently pre-treated samples (Table 2). $\mathrm{T}$ pre-treatment yielded $129 \mathrm{mg}$ of reducing sugars per gram of input biomass compared to $72 \mathrm{mg}$ obtained with untreated GR, meaning that hot water and pressure alone were able to produce a significant pre-treatment effect. However, $\mathrm{KOH}$ addition was determined to enhance the pre-treatment efficiency since $\mathrm{K}$ reactors reached, on average, a yield of $336 \mathrm{mg} \mathrm{g}^{-1}$ (Table 2). A similar sugar yield $\left(380 \mathrm{mg} \mathrm{g}^{-1}\right)$ after enzymatic hydrolysis following an alkaline pre-treatment of giant reed with comparable $\mathrm{NaOH}$ concentrations has been recently reported [31]. This proves that $\mathrm{NaOH}$ can be effectively replaced by $\mathrm{KOH}$ to pre-treat giant reed. The significantly lower sugar yields of washed compared to unwashed materials (54 and $301 \mathrm{mg} \mathrm{g}^{-1}$ for Tw and $\mathrm{Kw}$, respectively) are due to the washout of the solubilized dry matter and VS in particular (Tables 2 and 3). Obviously, in the reactors where the biomass was pre-treated and not washed, there was no biomass loss.

The $\mathrm{KOH}$ addition caused more intense solubilization of the biomass than without addition, as indicated by the percentage of biomass retained (Table 3). The washing step of the thermo-chemical pre-treated biomass $(\mathrm{Kw})$, in particular, led to a loss of $19 \%$ of the TS and $16 \%$ of the VS, compared to $5 \%$ losses without alkali (Tw). 
Table 2. Reducing sugar yields after enzymatic hydrolysis of differently pre-treated giant reed biomass.

\begin{tabular}{|c|c|c|c|c|}
\hline \multirow[b]{2}{*}{ Pre-Treatment ${ }^{1}$} & \multicolumn{4}{|c|}{ Reducing Sugar Yield } \\
\hline & \multicolumn{2}{|c|}{$\begin{array}{c}\mathrm{mg} \mathrm{g}^{-1} \\
\text { Pre-Treated } \\
\text { Dry Biomass }\end{array}$} & \multicolumn{2}{|c|}{$\begin{array}{c}\text { mg g }^{-1} \\
\text { Initial } \\
\text { Dry Biomass }\end{array}$} \\
\hline GR & 72 & $\mathrm{~d}^{2}$ & 72 & $\mathrm{~d}$ \\
\hline $\mathrm{T}$ & 129 & c & 129 & c \\
\hline Tw & 54 & d & 49 & $\mathrm{~d}$ \\
\hline K & 336 & $\mathrm{a}$ & 336 & a \\
\hline $\mathrm{Kw}$ & 301 & $b$ & 277 & $\mathrm{~b}$ \\
\hline
\end{tabular}

${ }^{1} \mathrm{GR}$ : untreated control; $\mathrm{T}: 121^{\circ} \mathrm{C}, 20^{\prime} ; \mathrm{K}: 0.135 \mathrm{~g} \mathrm{KOH} \mathrm{g}^{-1} \mathrm{VS}, 121^{\circ} \mathrm{C}, 20^{\prime} ; w$ : washing step after pre-treatment ${ }^{2}$ Means sharing common letters are not significantly different at $p<0.05$ according to Tukey Honestly Significant Difference test.

Table 3. Fiber composition of differently pre-treated giant reed after the washing step.

\begin{tabular}{ccc}
\hline & \multicolumn{3}{c}{ Pre-Treatment $^{\mathbf{1}}$} \\
\hline Trait & Tw & Kw \\
\hline TS, \% retained ${ }^{2}$ & Mean (SD) & Mean (SD) \\
VS, \% retained & $94.67(0.19)$ & $81.20(0.06)$ \\
Cellulose, \%DM ${ }^{3}$ & $95.00(0.23)$ & $83.90(0.13)$ \\
Hemicellulose, \%DM & $45.23(0.03)$ & $52.68(0.45)$ \\
Lignin, \%DM & $22.58(0.23)$ & $21.81(0.06)$ \\
\hline
\end{tabular}

${ }^{1} \mathrm{Tw}: 121^{\circ} \mathrm{C}, 20^{\prime}+$ washing; $\mathrm{Kw}: 0.135 \mathrm{~g} \mathrm{KOH} \mathrm{g}^{-1} \mathrm{VS}, 121^{\circ} \mathrm{C}, 20^{\prime}+$ washing. ${ }^{2}$ Percentage still present in the sample after the washing step. ${ }^{3}$ Percentage of dry matter.

As for the composition of the washed biomass, in the presence of alkali $(\mathrm{Kw})$, there was a relative enrichment in cellulose fraction compared to Tw (Table 3), whereas the concentrations of hemicellulose and lignin were similar. Likewise, in comparison to the untreated biomass of giant reed (Table 1), the retained biomass showed enrichment in holocellulose, whereas lignin concentration remained unchanged (Table 3). However, in any case, the washing step resulted in losses of biomass, as discussed in more detail below.

\subsection{Washing Effects}

Thermo-chemical pre-treatments can generate inhibitors that could negatively affect the $\mathrm{AD}$ process. Therefore, generally, before $\mathrm{AD}$ the pre-treated solid biomass is recovered and washed, while the liquid fraction is discarded. However, washing the biomass, besides removing inhibitors and residual alkali, also takes away the solubilized organic fraction of the pre-treated biomass consisting mostly of hemicellulose (Figure 1), which instead could be conveniently utilized during the $\mathrm{AD}$ process. The washing step after the $\mathrm{T}$ pre-treatment led to a remarkable loss of hemicellulose and barely affected lignin (Figure 1), while the washing step after the K pre-treatment resulted in a more evident loss of both lignin and hemicellulose (Figure 1) indicating that K pre-treatment was more effective than $\mathrm{T}$ in fiber destructuring. The cellulose losses were negligible both for Tw and Kw. However, since the losses of lignin in Kw were almost triple if compared with those in Tw (Figure 1), it is clear that in $\mathrm{Kw}$ the fraction of cellulose available to the enzymatic attack was higher than in Tw. This explains the higher saccharification yield in Kw than in Tw shown in Table 2, despite the larger hemicellulose losses. In particular, the washing step following $\mathrm{KOH}$-based pre-treatment allowed to remove $16 \%$ of initial lignin and also led to a loss of $25 \%$ of initial hemicellulose (Figure 1). 


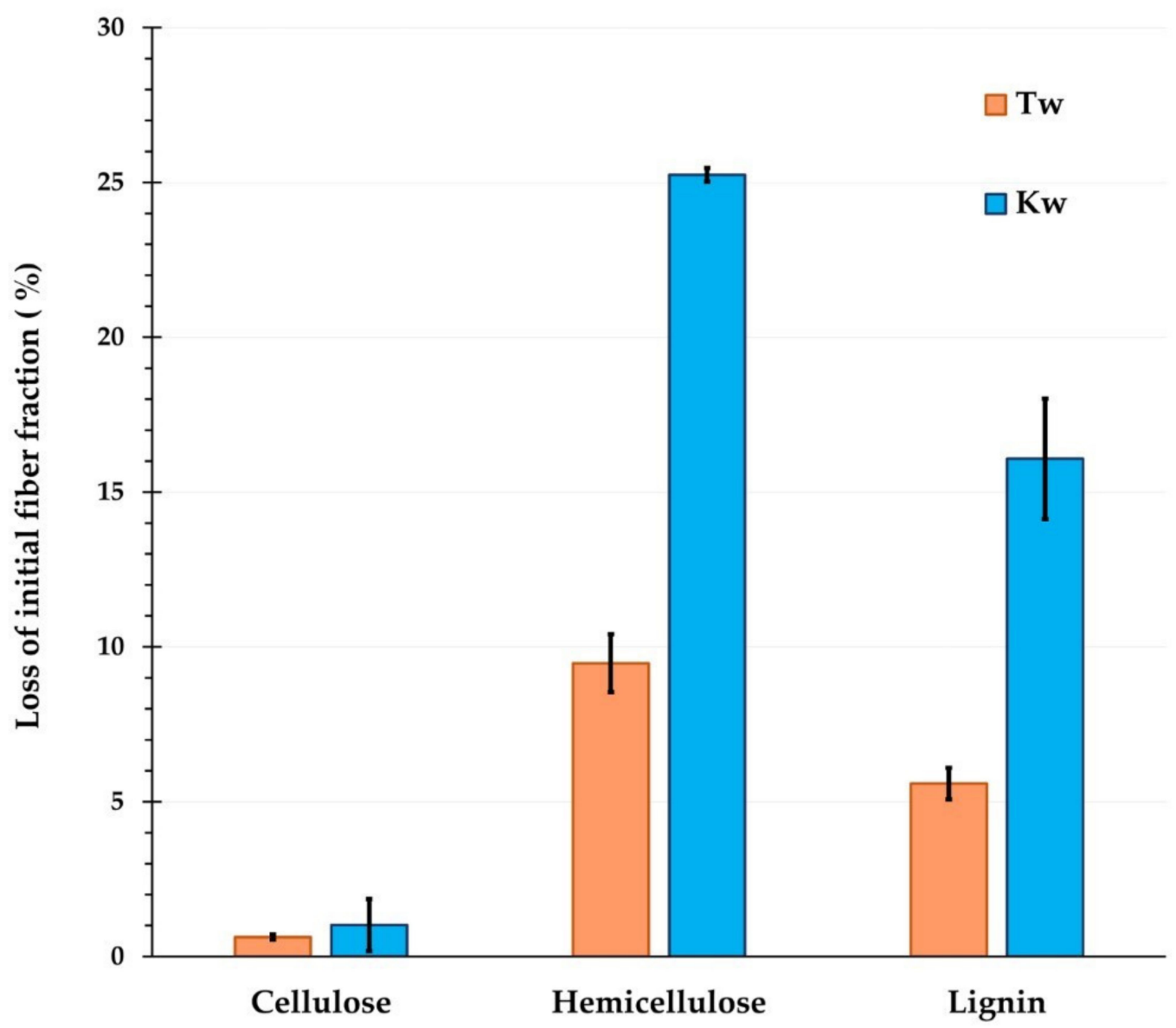

Figure 1. Loss (\%) of initial fiber fractions after the washing step following the pre-treatment with $\mathrm{KOH}(\mathrm{Kw})$ or without $\mathrm{KOH}(\mathrm{Tw})$. Vertical bars represent the standard deviation of the mean $(n=3)$.

Alkaline pre-treatments cause the solubilization of the hemicellulose since they break the hydrogen bonds [32]. Some authors reported 10-44\% lignin losses and 10-33\% losses of hemicellulose for giant reed pre-treated with $0.15-0.5 \mathrm{~N} \mathrm{NaOH}$ at $24-25^{\circ} \mathrm{C}$ for $24 \mathrm{~h}[12,17]$.

As far as $\mathrm{KOH}$-based pre-treatments are concerned, information on giant reed is not available in the literature. Wheat straw pre-treated with $\mathrm{KOH} 9 \% w / w$ at room temperature for 3 days showed $31 \%$ and $45 \%$ losses for lignin and hemicellulose, respectively [19]. On the other hand, when pre-treating wheat straw with $\mathrm{KOH} 50 \% w / w$ at $20^{\circ} \mathrm{C}$ for $24 \mathrm{~h}$, losses of $54.7 \%$ and $52.7 \%$ for lignin and hemicellulose, respectively, were recorded [33]. Asghar and colleagues [34] reported a delignification rate of over $60 \%$ pre-treating Kallar grass and cotton stalk with $\mathrm{KOH} 3 \% w / v$ for $48 \mathrm{~h}$ at room temperature, whereas a delignification rate

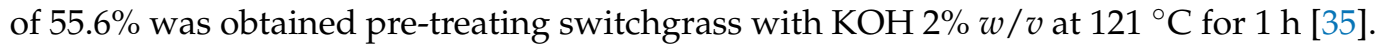
Therefore, lignin and hemicellulose losses after the washing step are generally substantial, although strongly influenced by both the type of biomass and pre-treatment severity.

In this study, differently from hemicellulose and lignin, cellulose solubilization was limited, and losses after the washing step were not detected (about 1\%) (Figure 1). Cellulose, indeed, under alkaline conditions is not easily hydrolyzed [11,33]. However, previously, cellulose losses between 16 and $20 \%$ had been reported, following a $\mathrm{NaOH}$ pre-treatment of giant reed [12,17]. Using $\mathrm{KOH}$ on wheat straw, cellulose losses between 12.6 and $13.5 \%$ had also been observed $[19,33]$. These larger losses could be due to differences in the solid/liquid separation procedure. 


\subsection{Effects of the Pre-Treatments on Anaerobic Digestion}

The highest $S M Y$ values (231 and $232 \mathrm{~mL} \mathrm{CH}_{4} \mathrm{~g}^{-1}$ VS) were obtained from K pretreated biomass, without any substantial difference between washed and unwashed samples (Figure 2; Table 4).

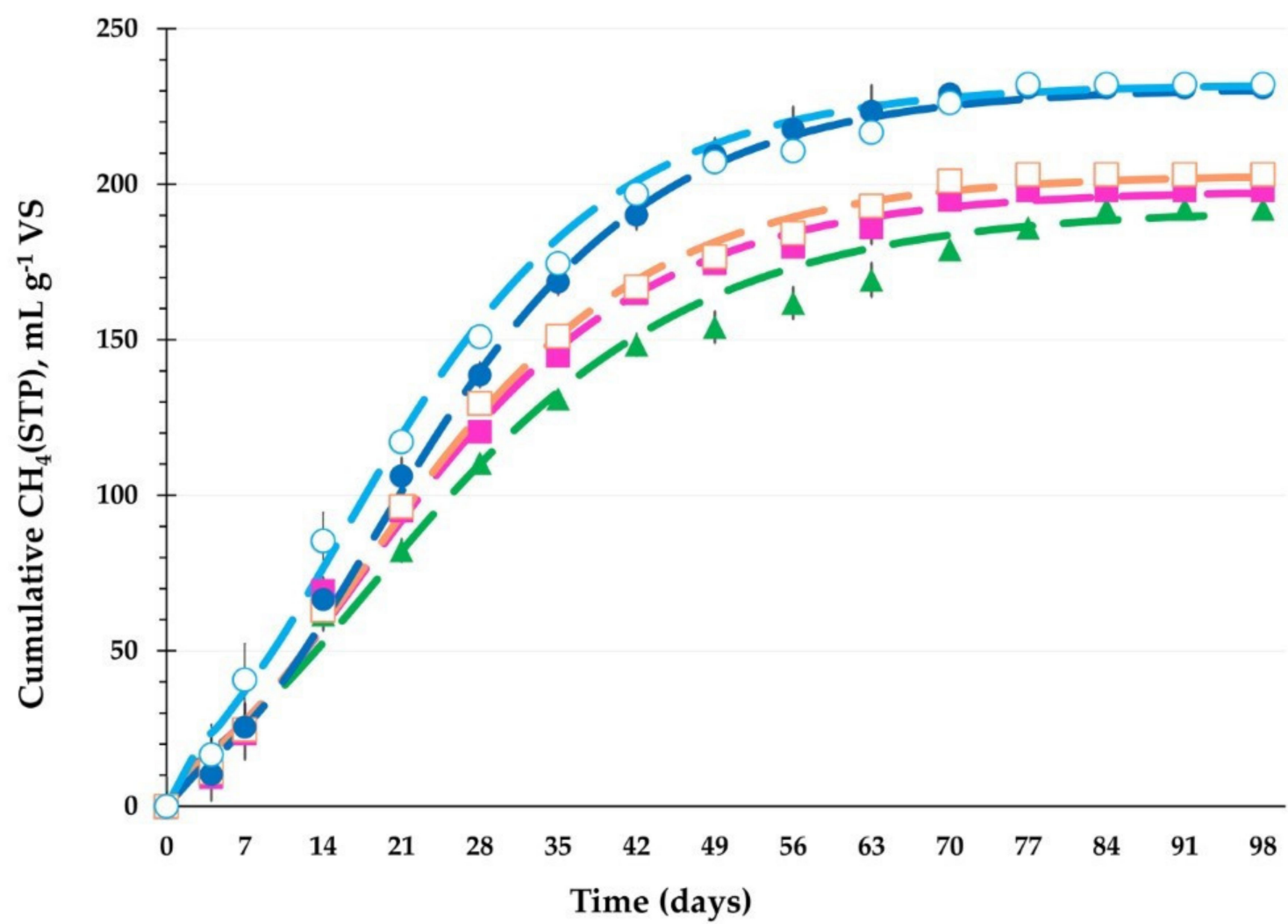

Figure 2. Measurements (points) and estimates (dashed curves) of the cumulative $\mathrm{CH}_{4}$ production from giant reed during anaerobic digestion. Circles: $\mathrm{KOH}$-based pre-treatments; squares: thermal pre-treatments; triangles: untreated giant reed. Empty symbols: washed samples; solid symbols: unwashed samples. Vertical bars represent the standard deviation of the mean $(n=3)$.

Table 4. Anaerobic digestion parameters of the differently pre-treated giant reed biomass.

\begin{tabular}{|c|c|c|c|c|c|c|c|c|c|c|c|c|}
\hline & \multicolumn{12}{|c|}{ Parameters ${ }^{2}$} \\
\hline & \multicolumn{2}{|c|}{$S M Y$} & \multicolumn{2}{|c|}{$R \max$} & \multicolumn{2}{|c|}{$\lambda$} & \multicolumn{2}{|c|}{ Time $\operatorname{Mmax}$} & \multicolumn{2}{|c|}{$\mathrm{CH}_{4} \max$} & \multicolumn{2}{|c|}{$A M P$} \\
\hline & \multicolumn{2}{|c|}{$\mathrm{mLCH}_{4} \mathrm{~g}^{-1} \mathrm{VS}$} & \multicolumn{2}{|c|}{$\mathrm{mL} \mathrm{CH}_{4} \mathrm{~d}^{-1}$} & \multicolumn{2}{|c|}{ d } & \multicolumn{2}{|c|}{ d } & \multicolumn{2}{|c|}{$\%$} & \multicolumn{2}{|c|}{$\mathrm{mLCH}_{4} \mathrm{~g}^{-1} \mathrm{VS}$} \\
\hline GR & 192 & $b^{3}$ & 4.26 & $\mathrm{~b}$ & 1.70 & $\mathrm{~b}$ & 46.8 & $\mathrm{a}$ & 47 & c & 192 & $\mathrm{~b}$ \\
\hline $\mathrm{T}$ & 198 & $\mathrm{~b}$ & 4.95 & $\mathrm{~b}$ & 2.38 & $\mathrm{~b}$ & 42.4 & $\mathrm{~b}$ & 49 & bc & 198 & $\mathrm{~b}$ \\
\hline Tw & 203 & $\mathrm{~b}$ & 5.02 & $\mathrm{~b}$ & 2.66 & $\mathrm{~b}$ & 43.5 & $a b$ & 48 & $\mathrm{bc}$ & 193 & $\mathrm{~b}$ \\
\hline K & 231 & a & 6.03 & a & 4.20 & a & 42.5 & $\mathrm{~b}$ & 58 & $\mathrm{a}$ & 231 & $\mathrm{a}$ \\
\hline $\mathrm{Kw}$ & 232 & $\mathrm{a}$ & 5.23 & $\mathrm{ab}$ & 1.69 & $\mathrm{~b}$ & 46.1 & $\mathrm{a}$ & 52 & $\mathrm{~b}$ & 195 & $\mathrm{~b}$ \\
\hline
\end{tabular}

${ }^{1} \mathrm{GR}$ : untreated control; $\mathrm{T}: 121^{\circ} \mathrm{C}, 20^{\prime} ; \mathrm{K}: 0.135 \mathrm{~g} \mathrm{KOH} \mathrm{g}^{-1} \mathrm{VS}, 121^{\circ} \mathrm{C}, 20^{\prime} ;$ w: washing step after pre-treatment. ${ }^{2}$ SMY: specific methane yield; Rmax: maximum daily rate production; $\lambda$ : lag phase duration; Time ${ }_{\text {Mmax }}$ : time to reach the maximum cumulative $\mathrm{CH}_{4}$ production; $\mathrm{CH}_{4}$ max: maximum content of $\mathrm{CH}_{4}$ in the biogas; $A M P$ : actual methane production $=S M Y$ multiplied by the percentage of retained VS.

${ }^{3}$ Means sharing common letters do not differ significantly at $p<0.05$ according to Tukey Honestly Significant Difference test.

These SMY values are in line with the $\mathrm{CH}_{4}$ yield obtained from other substrates commonly used in AD such as, for example, cattle slurry, wheat straw, vegetable waste, garden waste [3,36] or from Brassica napus which recently was reported to yield up to 
$259 \mathrm{~mL} \mathrm{CH}_{4} \mathrm{~g}^{-1} \mathrm{VS}$ when irrigated with abattoir wastewater [37]. In this study, untreated giant reed (GR) reached $192 \mathrm{~mL} \mathrm{CH}_{4} \mathrm{~g}^{-1} \mathrm{VS}$, which is consistent with what was reported by other authors for this crop $[17,38]$ and is comparable with the SMY of miscanthus, which varied between 166 and $202 \mathrm{~mL} \mathrm{CH}_{4} \mathrm{~g}^{-1} \mathrm{VS}$, depending on the genotype [18].

Therefore, the chemical pre-treatment of giant reed is necessary to achieve the $\mathrm{CH}_{4}$ yields obtained with other kinds of biomass commonly used to produce biogas, as SMY from just thermally pre-treated samples $(\mathrm{T})$ did not significantly differ from that of GR (Figure 2; Table 4).

On average, the $S M Y$ obtained from K reactors increased by $21 \%$ compared to the untreated GR (Table 4). Such an increase is consistent with that reported by Di Girolamo and colleagues [17] for giant reed pre-treated with $0.15 \mathrm{~N} \mathrm{NaOH}$ at $25^{\circ} \mathrm{C}$ for $24 \mathrm{~h}$. By using higher $\mathrm{NaOH}$ concentrations, Jiang and colleagues [12], obtained up to $63 \% \mathrm{CH}_{4}$ yield increase with $20 \mathrm{~g} \mathrm{~L}^{-1} \mathrm{NaOH}$, at $24{ }^{\circ} \mathrm{C}$ for $24 \mathrm{~h}$, while the pre-treatment of giant reed with $20 \mathrm{~g} \mathrm{~L}^{-1} \mathrm{CaOH}_{2}$ at $25{ }^{\circ} \mathrm{C}$ for $24 \mathrm{~h}$ allowed to increase $\mathrm{CH}_{4}$ yield by $34 \%$ compared to untreated [20]. This suggests that alkali type and concentration as well as pre-treatment conditions can affect the giant reed response in terms of $\mathrm{CH}_{4}$ yield.

Data referring to the effect of $\mathrm{KOH}$-based pre-treatments on $\mathrm{CH}_{4}$ yield from giant reed are not available in the literature. Previously, $\mathrm{KOH}$ was used to pre-treat agricultural residues: on wheat straw, concentrations of $\mathrm{KOH} \mathrm{g}{ }^{-1}$ TS between 1 and $9 \%$ at room temperature for 3 days were tested, obtaining a maximum increase of $\mathrm{CH}_{4}$ yield of $40 \%$ for $\mathrm{KOH}$ at 6\% [19] whereas, Liu and colleagues [33] testing concentrations between 2 and $50 \% \mathrm{~g} \mathrm{KOH} \mathrm{g}^{-1}$ dry straw at $20{ }^{\circ} \mathrm{C}$ for $24 \mathrm{~h}$, reported that the pre-treatment with $20 \% \mathrm{KOH}$ was the most favorable allowing a $44 \%$ increase in SMY, while $\mathrm{KOH}$ concentration of $14 \%$, very similar to that used in this study, increased $\mathrm{CH}_{4}$ production by $26 \%$. For corn stover, $\mathrm{KOH}$ was reported as more effective than $\mathrm{Ca}(\mathrm{OH})_{2}$ : the maximum increase in terms of $\mathrm{CH}_{4}$ yield was $95 \%$ for $\mathrm{KOH} 2.5 \%$ w/v and only $40 \%$ for $2.5 \% \mathrm{Ca}(\mathrm{OH})_{2} w / v$ [39]. $\mathrm{KOH}$ also outperformed $\mathrm{NaOH}$ on wheat straw: pre-treating wheat straw at $19{ }^{\circ} \mathrm{C}$ for $24 \mathrm{~h}$ with $0.5 \%$ $\mathrm{KOH} w / w$ increased $\mathrm{CH}_{4}$ yield by $23 \%$, as with $2 \% \mathrm{NaOH} w / w$ [40].

An effective pre-treatment also influences the daily production rate of $\mathrm{CH}_{4}(\mathrm{Rmax})$. This is because the pre-treatment makes the holocellulose polymers more readily attackable by the hydrolytic enzymes produced by bacteria involved in AD. In this study, the thermochemical pre-treatment led to a significant increase in Rmax especially from the unwashed biomass (Table 4). Significant differences were not detected between $\mathrm{T}$ and GR reactors in terms of Rmax value. The Rmax value obtained from the $\mathrm{K}$ reactors was $42 \%$ higher than that from GR (6.03 VS $4.26 \mathrm{~mL} \mathrm{CH}_{4} \mathrm{~d}^{-1}$, respectively). Using a higher alkali concentration, Jiang and colleagues [12], reported an almost $100 \%$ increase of Rmax compared to the control for giant reed pre-treated with $\mathrm{NaOH} 20 \mathrm{~g} \mathrm{~L}^{-1}$. For wheat straw pre-treated with $\mathrm{KOH}$ concentration similar to that used in this study, Liu and colleagues [33] reported a $67 \%$ increase of Rmax, compared to the control.

Overall, AD had a regular course in all reactors (Figure 2); $\mathrm{CH}_{4}$ production started simultaneously in all reactors except for $\mathrm{K}$ where the lag phase $(\lambda)$ was significantly the longest (Table 4). However, in these reactors, the significantly highest value of Rmax was

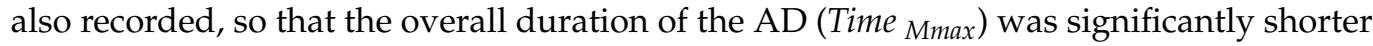
in $\mathrm{K}$ compared to its washed equivalent (Kw) and GR (Table 4 ). The presence of the pretreatment liquid fraction did not negatively affect $\mathrm{CH}_{4}$ production: the unwashed reactors (K), indeed, provided SMY and Rmax values similar to the washed reactors. Besides, the highest $\mathrm{CH}_{4}$ concentration in the biogas $\left(\mathrm{CH}_{4}\right.$ max) was obtained in $\mathrm{K}$ reactors and reached $58 \%$. The only negative effect attributable to the presence of the pre-treatment liquid fraction can be recognized in the significantly longer lag phase duration of $\operatorname{AD}(\lambda)$ in $K$ reactors (4.2 days), which was almost 2.5 times longer than that of the Kw reactors (Table 4). Among the inhibitors that can accumulate in the residual liquid fraction of the thermo-alkaline pre-treatment, there are the polyphenols released due to lignin destructuring $[2,6,41]$. Some authors have described the toxic effects of polyphenols on methanogens [42,43]. In a previous study, polyphenols were responsible for a delay in the start of AD of the spent 
coffee ground [44], thus the lengthening of the lag phase observed for $\mathrm{K}$ in this study can be due to polyphenols presence. However, the inhibitory effect finished within the first 4 days and the time required to complete the $\mathrm{AD}$ was even found to be significantly shorter in the unwashed reactors than in the washed ones, which had an AD duration identical to that of untreated giant reed (Table 4).

The washing step, in addition to removing inhibitors and lignin, also led to the loss of material suitable for $\mathrm{AD}$ as demonstrated by the higher overall methane yield $(A M P)$ obtained from $\mathrm{K}$ reactors compared to $\mathrm{Kw}$ (231 vs. $195 \mathrm{~mL} \mathrm{~g}^{-1} \mathrm{VS}$, respectively; Table 4). Indeed, due to the biomass losses following the washing step, the AMP from Kw reactors was not significantly different from that of GR, reducing the pre-treatment advantages (Table 4). This evidence is consistent with the literature: taking into account the biomass losses due to the removal of the liquid fraction, Liu and colleagues [33] did not find significant differences between $14 \% \mathrm{KOH}$ pre-treated or untreated wheat straw in terms of overall $\mathrm{CH}_{4}$ produced, despite a significant specific methane yield increase.

Our results demonstrate that the liquid fraction derived from the pre-treatment not only did not inhibit $\mathrm{AD}$ but also contributed to $\mathrm{CH}_{4}$ production. This is supported also by the observation that the unwashed $\mathrm{KOH}$ pre-treated materials displayed the highest saccharification yield (Table 2), meaning that the liquid fraction contained readily digestible carbohydrates.

In conclusion, avoiding the washing step not only permits to increase $\mathrm{CH}_{4}$ production per initial biomass input unit but also alleviates the problem of disposing of saline wastewater, reducing the overall pre-treatment costs. Besides, the pre-treatment with $\mathrm{KOH}$ instead of $\mathrm{NaOH}$ would result in a digestate enriched in potassium, that could be utilized as fertilizer [19].

\section{Conclusions}

The thermo-chemical pre-treatment with $\mathrm{KOH}$ caused an efficient deconstruction of lignocellulosic biomass of giant reed, allowing an increase of $\mathrm{CH}_{4}$ yield by $21 \%$. Besides, the maximum daily rate of production increased by $42 \%$, and $\mathrm{CH}_{4}$ concentration in the biogas by $23 \%$, while $\mathrm{AD}$ duration was reduced by $10 \%$, compared to thermal pre-treatment or untreated control. The washing step resulted unnecessary since the liquid fraction derived from the pre-treatment negatively affected only the lag phase. Methane production from the washed pre-treated biomass did not differ from that of the untreated, due to the biomass loss that occurred after the washing step. Thus, the use of a $\mathrm{KOH}$-based pre-treatment without washing appears as a good option for enhancing the methane yield of giant reed. Further studies are necessary to optimize pre-treatment conditions and $\mathrm{KOH}$ concentration.

Author Contributions: Conceptualization, C.V., S.C., R.M., and S.G.; methodology, C.V., S.C., R.M., and S.G.; validation, C.V. and S.C.; formal analysis, R.M.; investigation, C.V. and S.C.; resources, S.G.; data curation, C.V.; writing-original draft preparation, C.V. and S.C.; writing-review and editing, C.V., S.C., R.M., E.C., and S.G.; visualization, C.V.; supervision, R.M., E.C., and S.G.; project administration, R.M. and S.G.; funding acquisition, R.M. and S.G. All authors have read and agreed to the published version of the manuscript.

Funding: This research was funded by the Italian Ministry of Agricultural, Food and Forestry Policies (MiPAAF) under the AGROENER project (D.D. n. 26329, 1 April 2016) http:/ / agroener.crea.gov.it.

Institutional Review Board Statement: Not applicable.

Informed Consent Statement: Not applicable.

Data Availability Statement: The data presented in this study are available on request from the corresponding author.

Acknowledgments: Authors wish to thank Anna Orsi for laboratory analyses and assistance.

Conflicts of Interest: The authors declare no conflict of interest. The funders had no role in the design of the study; in the collection, analyses, or interpretation of data; in the writing of the manuscript, or in the decision to publish the results. 


\section{References}

1. Gunes, B.; Stokes, J.; Davis, P.; Connolly, C.; Lawler, J. Optimisation of anaerobic digestion of pot ale after thermochemical pre-treatment through Response Surface Methodology. Biomass Bioenergy 2021, 144, 105902. [CrossRef]

2. Wagner, A.O.; Lackner, N.; Mutschlechner, M.; Prem, E.M.; Markt, R.; Illmer, P. Biological pretreatment strategies for secondgeneration lignocellulosic resources to enhance biogas production. Energies 2018, 11, 1797. [CrossRef]

3. Edwiges, T.; Bastos, J.A.; Alino, J.H.L.; d'Avila, L.; Mantovani Frare, L.; Somer, J.-G. Comparison of various pretreatment techniques to enhance biodegradability of lignocellulosic biomass for methane production. J. Environ. Chem. Eng. 2019, 7, 103495. [CrossRef]

4. Novakovic, J.; Kontogianni, N.; Barampouti, E.M.; Mai, S.; Moustakas, K.; Malamis, D.; Loizidou, M. Towards upscaling the valorization of wheat straw residues: Alkaline pretreatment using sodium hydroxide, enzymatic hydrolysis and biogas production. Environ. Sci. Pollut. Res. 2020. [CrossRef] [PubMed]

5. Scordia, D.; Cosentino, S.L. Perennial Energy Grasses: Resilient Crops in a Changing European Agriculture. Agriculture 2019, 9 , 169. [CrossRef]

6. Kovačić, Đ.; Kralik, D.; Rupcic, S.; Jovicic, D.; Spajić, R.; Tišma, M. Soybean straw, corn stover and sunflower stalk as possible substrates for biogas production in Croatia: A review. Chem. Biochem. Eng. Q. 2017, 31, 187-198. [CrossRef]

7. Achinas, S.; Achinas, V.; Euverink, G.J.W. A technological overview of biogas production from biowaste. Engineering 2017, 3, 299-307. [CrossRef]

8. Cianchetta, S.; Di Maggio, B.; Burzi, P.L.; Galletti, S. Evaluation of selected white-rot fungal isolates for improving the sugar yield from wheat straw. Appl. Biochem. Biotechnol. 2014, 173, 609-623. [CrossRef] [PubMed]

9. Yang, L.; Xu, F.; Ge, X.; Li, Y. Challenges and strategies for solid-state anaerobic digestion of lignocellulosic biomass. Renew. Sust. Energ. Rev. 2015, 44, 824-834. [CrossRef]

10. Kumar, P.; Barrett, D.M.; Delwiche, M.J.; Stroeve, P. Methods for pretreatment of lignocellulosic biomass for efficient hydrolysis and biofuel production. Ind. Eng. Chem. Res. 2009, 48, 3713-3729. [CrossRef]

11. Monlau, F.; Barakat, A.; Steyer, J.P.; Carrere, H. Comparison of seven types of thermo-chemical pretreatments on the structural features and anaerobic digestion of sunflower stalks. Bioresour. Technol. 2012, 120, 241-247. [CrossRef] [PubMed]

12. Jiang, D.; Ge, X.; Zhang, Q.; Li, Y. Comparison of liquid hot water and alkaline pretreatments of giant reed for improved enzymatic digestibility and biogas energy production. Bioresour. Technol. 2016, 216, 60-68. [CrossRef] [PubMed]

13. Surendra, K.C.; Sawatdeenarunat, C.; Shrestha, S.; Sung, S.; Khanal, S.K. Anaerobic digestion-based biorefinery for bioenergy and biobased products. Ind. Biotechnol. 2015, 11, 103-112. [CrossRef]

14. D'Imporzano, G.; Pilu, R.; Corno, L.; Adani, F. Arundo donax L. can substitute traditional energy crops for more efficient, environmentally-friendly production of biogas: A Life Cycle Assessment approach. Bioresour. Technol. 2018, 267, 249-256. [CrossRef]

15. Ceotto, E.; Castelli, F.; Moschella, A.; Diozzi, M.; Di Candilo, M. Cattle slurry fertilization to giant reed (Arundo donax L.): Biomass yield and nitrogen use efficiency. BioEnergy Res. 2015, 8, 1252-1262. [CrossRef]

16. Cianchetta, S.; Bregoli, L.; Galletti, S. Microplate-based evaluation of the sugar yield from giant reed, giant Miscanthus and switchgrass after mild chemical pre-treatments and hydrolysis with tailored Trichoderma enzymatic blends. Appl. Biochem. Biotech. 2017, 183, 876-892. [CrossRef]

17. Di Girolamo, G.; Bertin, L.; Capecchi, L.; Ciavatta, C.; Barbanti, L. Mild alkaline pre-treatments loosen fibre structure enhancing methane production from biomass crops and residues. Biomass Bioenergy 2014, 71, 318-329. [CrossRef]

18. Thomas, H.L.; Arnoult, S.; Brancourt-Hulmel, M.; Carrère, H. Methane production variability according to Miscanthus genotype and alkaline pretreatments at high solid content. Bioenerg. Res. 2019, 12, 325-337. [CrossRef]

19. Jaffar, M.; Pang, Y.; Yuan, H.; Zou, D.; Liu, Y.; Zhu, B.; Korai, R.M.; Li, X. Wheat straw pretreatment with KOH for enhancing biomethane production and fertilizer value in anaerobic digestion. Chin. J. Chem. Eng. 2016, 24, 404-409. [CrossRef]

20. Jiang, D.; Ge, X.; Zhang, Q.; Zhou, X.; Chen, Z.; Keener, H.; Li, Y. Comparison of sodium hydroxide and calcium hydroxide pretreatments of giant reed for enhanced enzymatic digestibility and methane production. Bioresour. Technol. 2017, 244, 1150-1157. [CrossRef]

21. Vasmara, C.; Cianchetta, S.; Marchetti, R.; Galletti, S. Biogas production from wheat straw pre-treated with ligninolytic fungi and co-digestion with pig slurry. Environ. Eng. Manag. J. 2015, 14, 1751-1760. [CrossRef]

22. Vasmara, C.; Marchetti, R. Biogas production from biodegradable bioplastics. Environ. Eng. Manag. J. 2016, 15, 2041-2048. [CrossRef]

23. Zwietering, M.H.; Jongenburger, I.; Rombouts, F.M.; van't Riet, K. Modeling of the bacterial growth curve. Appl. Environ. Microbiol. 1990, 56, 1875-1881. [CrossRef] [PubMed]

24. APHA. Standard Methods for the Examination of Water and Wastewater, 18th ed.; American Public Health Association: Washington, DC, USA, 1992.

25. Van Soest, P.J.; Robertson, J.B.; Lewis, B.A. Methods for dietary fiber, neutral-detergent fiber and non-starch polysaccharides in relation to animal nutrition. J. Dairy Sci. 1991, 74, 3583-3597. [CrossRef]

26. Miller, G.L. Use of dinitrosalicylic acid reagent for determination of reducing sugar. Anal. Chem. 1959, 31, 426-428. [CrossRef]

27. Cianchetta, S.; Galletti, S.; Burzi, P.L.; Cerato, C. Hydrolytic potential of Trichoderma sp. strains evaluated by microplate-based screening followed by switchgrass saccharification. Enzyme Microb. Technol. 2012, 50, 304-310. [CrossRef] [PubMed] 
28. SAS Institute. SAS/STAT TM Guide for Personal Computers, Version 6, 2nd ed.; SAS Institute: Cary, NC, USA, 1987.

29. Littell, R.C.; Milliken, G.A.; Stroup, W.W.; Wolfinger, R.D. SAS system for Mixed Models; SAS Institute Inc.: Cary, NC, USA, 1996.

30. Cianchetta, S.; Nota, M.; Polidori, N.; Galletti, S. Alkali pre-treatment and enzymatic hydrolysis of Arundo donax for single cell oil production. Environ. Eng. Manag. J. 2019, 18, 1693-1701.

31. Lemões, J.S.; e Silva, C.F.L.; Avila, S.P.F.; Montero, C.R.S.; e Silva, S.D.D.A.; Samios, D.; Peralba, M.D.C.R. Chemical pretreatment of Arundo donax L. for second-generation ethanol production. Electron. J. Biotechn. 2018, 31, 67-74. [CrossRef]

32. Xiao, B.; Sun, X.F.; Sun, R. Chemical, structural, and thermal characterizations of alkali-soluble lignins and hemicelluloses, and cellulose from maize stems, rye straw, and rice straw. Polym. Degrad. Stab. 2001, 74, 307-319. [CrossRef]

33. Liu, X.; Zicari, S.M.; Liu, G.; Li, Y.; Zhang, R. Pretreatment of wheat straw with potassium hydroxide for increasing enzymatic and microbial degradability. Bioresour. Technol. 2015, 185, 150-157. [CrossRef]

34. Asghar, U.; Irfan, M.; Nadeem, M.; Nelofer, R.; Syed, Q. Effect of KOH pretreatment on lignocellulosic waste to be used as for ethanol production. Iran. J. Sci. Technol. Trans. Sci. 2017, 41, 659-663. [CrossRef]

35. Sharma, R.; Palled, V.; Sharma-Shivappa, R.R.; Osborne, J. Potential of potassium hydroxide pretreatment of Switchgrass for fermentable sugar Production. Appl. Biochem. Biotechnol. 2013, 169, 761-772. [CrossRef] [PubMed]

36. Scarlat, N.; Dallemand, J.-F.; Fahl, F. Biogas: Developments and perspectives in Europe. Renew. Energy 2018, 129, 457-472. [CrossRef]

37. Shilpi, S.; Lamb, D.; Bolan, N.; Seshadri, B.; Choppala, G.; Naidu, R. Waste to watt: Anaerobic digestion of wastewater irrigated biomass for energy and fertiliser production. J. Environ. Manag. 2019, 239, 73-83. [CrossRef] [PubMed]

38. Ceotto, E.; Vasmara, C.; Marchetti, R.; Cianchetta, S.; Galletti, S. Biomass and methane yield of giant reed (Arundo donax L.) as affected by single and double annual harvest. GCB Bioenergy 2021, 1-15. [CrossRef]

39. Li, L.; Chen, C.; Zhang, R.; He, Y.; Wang, W.; Liu, G. Pretreatment of corn stover for methane production with the combination of potassium hydroxide and calcium hydroxide. Energ. Fuel. 2015, 29, 5841-5846. [CrossRef]

40. Moset, V.; Xavier, C.d.A.N.; Feng, L.; Wahid, R.; Møller, H.B. Combined low thermal alkali addition and mechanical pre-treatment to improve biogas yield from wheat straw. J. Clean Prod. 2018, 172, 1391-1398. [CrossRef]

41. Sawatdeenarunat, C.; Surendra, K.C.; Takara, D.; Oechsner, H.; Khanal, S.K. Anaerobic digestion of lignocellulosic biomass: Challenges and opportunities. Bioresour. Technol. 2015, 178, 178-186. [CrossRef]

42. Field, J.A.; Lettinga, G. The methanogenic toxicity and anaerobic degradability of a hydrolyzable tannin. Water Res. 1987, 21, 367-374. [CrossRef]

43. Kayembe, K.; Basosila, L.; Mpiana, P.T.; Sikulisimwa, P.C.; Mbuyu, K. Inhibitory ffects of phenolic monomers on methanogenesis in anaerobic digestion. Br. Microbiol. Res. J. 2013, 3, 32-41. [CrossRef]

44. Vasmara, C.; Marchetti, R. Spent coffee grounds from coffee vending machines as feedstock for biogas production. Environ. Eng. Manag. J. 2018, 17, 2813-2821. 